\title{
THE ATHEIST REGIME IN THE MOLDAVIAN SSR: MINISTERS AND ICONS
}

\author{
Octavian MoșIN*
}

\begin{abstract}
Anti-religious policy and atheistic propaganda had a disastrous effect on the Church in the Moldavian SSR. During Soviet domination, the number of atheists and unbelievers increased considerably. Communist authorities have done their best to erase any trace of the Christian faith in the Prut-Dniester area, so that all spiritual manifestations and strength should disappear with it. Elimination of persons and destruction of everything sacred were attempted.
\end{abstract}

Keywords: atheist regime, communist ideology, icons, hierarchs, empowered, Soviet period

\section{Introduction: Anti-religious policy}

Every visible and invisible creature was created by God out of love. Man, the crown of all creation, has the highest purpose of all beings: to be in an uninterrupted connection with his Creator, his Heavenly Father, to know His will and to fulfil it. By knowing God and fulfilling His will, man can reach perfection and salvation.

For over two millennia, God's teachings, brought by the Saviour Christ, encountered opposition and even persecution. However, the Christian Church has always passed through sacrifice and persecution on to triumph. The history of Christianity includes names of martyrs who, at different times and in different circumstances, have suffered in Christ and have become 'heroes' of Christianity.

Church life in the Prut-Dniester area, in the twentieth century, was deeply marked by a series of events that radically changed its course

*PhD, Lecturer, "C. Stere" University of European Political and Economic Studies, Chişinău, Republic of Moldova. 
several times. After the Soviets came in 1940, the Church went through a real ordeal. One of the essential problems of communist ideology was religion, and the Soviet State imposed an anti-religious policy on to local population. One of the first actions of the Soviet authorities against the Church in this area was Decision no. 142-H, dated September 13, 1940 "On confiscation of religious books of all rites and religious denominations" ". Within 10 days, municipal and county committees were established to enforce the decision. Christian education schools were closed. In 1940, the first steps towards secularization of places of holiness were applied in Bessarabia. Pioneers Palace was installed inside the Chapel of Metropolitan Palace in Chisinau. The building of the Theological Seminary, the Chapel of the Seminary, and other sacred places, were used contrary to their purposes. Originally converted into a cultural centre (entertainment place for the security agents (NKVD agents)), the Church of the Seminary became the History Archive of the People's Commissariat for Internal Affairs (NKVD).

In order to maintain control over the religious life in Bessarabia, the communist authorities established a policy of terror over the activity of churches and clergy. Churches and clergymen officiating the service were taxed. Additional charges were levied during major holidays.

From the first days of Soviet occupation, most churches, especially in Chisinau, were looted. Sacred places were stripped of holy garments, icons and other valuables. The collection of books, albums and historical valuables of the Historical and Archaeological Eparchial Museum were seized and sent to the USSR.

Between 1941 and 1944, under certain historical circumstances, the Church entered a time of evolution and restoration of the damages, until the totalitarian regime was reinstalled.

Between 1944 and 1989, the religious life in MSSR experienced a bleak, negative phase. The Soviet authorities continued the anti-religious policy by imposing communist ideology. Because of this ideology, a mechanism was in place to conduct their activity. Soviet authorities applied the laws that were in force in the USSR. Thus, a Moscow empowered representative function was introduced to monitor the religious affairs in the MSSR, with the task to liaise between the

\footnotetext{
${ }^{1}$ Arhiva Națională a Republicii Moldova (hereinafter: ANRM), F.3046, inv.1, d.8, f.85.
} 
ARS LITURGICA. From the Image of Glory to the Images of the Idols of Modernity communist state and the Church ${ }^{2}$. The official occupying this position had great powers, and Chisinau hierarchs could not take any action without his consent.

The documents in the National Archives of the Republic of Moldova show that the Bessarabian clergy's fate was determined by the diabolical machine of the NKVD. Many priests were shot or deported. Some of the altar servants have carried their cross in communist prisons in remote regions of Siberia. Some of them could see the end of the atheist regime, others died wishing for the moment of its collapse. Those who returned from exile or prison were subjected to intimidation and persecution by various methods: cast out of parish, forced to pay high taxes or threatened with Siberia. Throughout the Soviet period, there were cases when the more active priests were treated as religious fanatics.

Since the activity of the Church was incompatible with the policy of the communist regime, it was always marginalized, being considered a dangerous institution and was subjected to strict control by the authorities. Thus, secret agents and informants infiltrated the Church organizations. They also occupied leadership positions in the Church hierarchy. In this way, the communist regime wanted to destroy the Church from within. Agents collected compromising material against the most active ministers, which could serve as a reason for their exclusion from the clergy or even for arrest. There were no actual reasons, they had to be invented by the 'laboratories of the Security'. Secret agents would track where and when priests were performing religious services, what was the content of sermons, their correspondence was checked. Many priests no longer preached because they did not want to conflict with the State authorities. Those who resisted or broke the rules imposed by the Soviet regime were charged; after which, at best, they were stopped from performing divine services and removed from the clergy; at worst, they

${ }^{2}$ On 7 October 1943, by decision of the Central Committee of USSR Communist Party, the "Council of the Russian Orthodox Church" was created, reporting to the government. The Committee's regulations empowered its leadership and representatives in the field with the supervision of churches throughout the Soviet Union. They were entitled to ask central and local Soviet authorities all information and materials on the activities of the Orthodox Church. See: V. PASAT, Aspru adevăr al istoriei. Deportările de pe teritoriul RSS Moldoveneşti în anii 1940-1950, Chişinău, 2000 . 
were arrested and sentenced to many years in prison.

As a result, even in the early years of anti-religious policy 'implementation', many priests and monks were arrested, accused of antiSoviet activity. In most cases, those who suffered were those who manifested the most zeal, who continued preaching, who worked with children and youth, who taught the faithful to oppose closures of churches and submit applications to reopen non-registered sanctuaries, etc. ${ }^{3}$ Among the arrested and convicted clergy are priest Vladimir Ababii (sentenced to 6 years in 1947); abbot Serafim Dabija, priest Elpidifor Zavitchi, priest Antonie Babcenco, priest Ioan Comerzan (sentenced to 10 years in 1947); priest Alexandru Coroli, monk Teofan Danilov, hieromonk Macarie Holmitchii (sentenced to 15 years in 1948); hieromonk Mercurie Iatco, monk Nichifor Ciobanu (sentenced to 10 years in 1948), etc. ${ }^{4}$ These are just a few names of those who suffered for the faith.

Another aspect kept under control by the Soviet authorities during the atheist regime was the education of clergy and theological studies. The number of candidates from MSSR eager to be enrolled in theological seminaries in Ukraine and Russia was regulated and permanently reduced by secret agents. In addition, authorities watched through these agents to ensure that those ordained were not among the best, passing those with low-intellectual levels.

The policy of maintaining the communist regime through terror seriously affected religious buildings. Much sanctuaries were demolished, others, transformed into clubs, gyms, and libraries. Naşterea Domnului [Nativity] Cathedral in downtown Chisinau saw great hardships as well. In 1961, it was transformed into an exhibition hall for the Museum of Fine Arts of the Ministry of Culture in MSSR. The Council of Ministers decided in February 1963, to demolish the Cathedral bell tower in Chisinau. The impetus of this decision was a letter from the Party organization within the Agricultural Institute in Chisinau, which demanded the demolition of the bell tower, arguing that it was ruining the

3 Veaceslav CionBă, Biserica Ortodoxă din Basarabia şi Transnistria (1940-2010), Chişinău, Pontos, 2011, p.195.

${ }^{4}$ Иосиф ПАвлинчук,Кишиневско-Молдавская Епархия в период с 1944 по 1989 год, Ново-Нямецкий монастырь, Издательство Ново-Нямецкого монастыря, 2004, p. 278. 
ARS LITURGICA. From the Image of Glory to the Images of the Idols of Modernity architectural style of Chisinau. At night, the bell tower was demolished by blasting and fresh earth and grass were put in its place, so no trace of the bell tower remained ${ }^{5}$.

\section{Anti-religious propaganda}

Another way to get people to deny faith was anti-religious propaganda. A Museum of Atheism operated in Chisinau - the third in the Soviet Union. The Museum of Atheism was the greatest propaganda tool against the faith. After most churches in Moldova were destroyed, the first museum of scientific atheism was founded in Chisinau in 1977. This museum was conceived as an institution of religious and atheist heritage preservation and accumulation, but especially as an important centre for anti-religious propaganda. During its activity, the most important valuables of the Museum of Atheism included collections of religious books, objects and icons. Before closing the Museum of Atheism in Chisinau, the process of restitution of objects collected from churches began. In 1992, the Museum of Atheism was closed and exhibits were transferred to the National Museum of Archaeology and History of Moldova. All items have been organized in a permanent exhibition that can be visited at any time ${ }^{6}$.

Anti-religious policy and atheistic propaganda had a disastrous effect on the Church in the Moldavian SSR. During Soviet domination, the number of atheists and unbelievers increased considerably. Communist authorities did their best to erase any trace of the Christian faith in the Prut-Dniester area, so that all spiritual manifestations and strength to disappear with it.

\section{Hierarchs' activities in the Soviet period (1944-1989)}

With the establishment of the totalitarian communist regime, the Orthodox Church in Moldavian SSR fell under the unconditional jurisdiction of the Russian Patriarchate and became a simple Episcopate. Candidates to the episcopal chair were appointed by the Holy Synod of

${ }^{5}$ Ludmila Tıhonov, Politica Statului Sovietic faţă de cultele din R.S.S. Moldovenească (1944-1965), Chişinău, Prut Internaţional, 2004.

${ }^{6} \mathrm{http} / / /$ moldnova.eu/ro/muzeul-ateismului-de-la-chisinau-locul-de-unde-izvora-propaganda-antireligioasa-2468.html/ (Accessed March 9, 2017). 
the Russian Orthodox Church amongst Russian ministers. During the atheist regime in 1944-1989, at the helm of the Eparchy no native clergyman was among them.

The first Russian hierarch appointed by the Holy Synod of the Russian Orthodox Church in Chisinau after 1944 was Bishop IeronimZaharov.The High Bishop pastored in these places between 1944 and 1947.

In the official sources his activity in Moldova's lands is characterized as a positive one, as well as by the researchers who wrote about him. Bishop IeronimZaharov came to Chisinau at a time when the country was in ruins from the war and the population was afflicted by poverty, hunger, repression, etc.

The hierarch had to make every effort to bring order to the religious life of MSSR under atheist regime. A merit of his was striving to fill the churches with priests, because the situation was such that a priest was serving 5-7 churches. Also, Bishop Ieronim ordained more priests, usually older church singers who were graduates of schools of singers around monasteries ${ }^{7}$.

The archival documents show, however, a picture quite different from that described above, concerning the activity of Bishop Ieronim at Chisinau. Thus, the empowered representative's report of 1946 said: "All religious activities in the Eparchy has been only coordinated by the bishop. No eparchial administrative apparatus has been established. (...) he had no authority in front of the clergy, and clergy was unhappy with his work" "Other documents show that countless letters and complaints were sent to authorities by citizens and clergy, listing their discontent with the activity and behaviour of the hierarch. He constantly went to Moscow. He had no Eparchial Council or Chancellery. He ruled alone 9 .

Because the primary mission of Bishop Ieronim to restore the church life affected by the war and to organize a new Eparchy of Chisinau and Moldova following the models of the Russian Eparchies was not met, the church authorities in Moscow took into consideration his failure to

${ }^{7}$ V.CIORBĂ,op.cit., p.173.

${ }^{8}$ Валериу ПАСАТ (отв. ред.), Православие в Молдавии: власть, церковь, верующие. 1940-1991, T.1, 1940-1953, Москва, Российская политическая энциклопедия, 2009, p.238, 259-260.

${ }^{9}$ Ibidem,p.78. 
meet his duties and decided to transfer him to another Eparchy.

The next candidate for the episcopal chair in Chisinau was chosen from among local Russians, widower Archpriest Vladimir - Bishop Benedict Poliakov, who served between 1947 and 1948.

He took an Eparchy full of debt. Lack of clergy, their intimidation and arrest did not impede him from exercising his mission responsibly. At his initiative, there was established an Eparchial Council, consisting of three archpriests ${ }^{10}$. He obtained the permission of the authorities to organise short-term courses for priests who had no theological studies. As a result, during his quite short pastoral period, a record number of 95 priests were ordained ${ }^{11}$. Bishop Benedict supported all efforts of the faithful towards the empowered representative, for opening closed places of holiness and, in his time, another 20 churches were registered with great difficulty. Whenever possible, he also supported the monasteries. Hieromonks distributed among parishes were obliged to aid the genuflection monasteries ${ }^{12}$. The hierarch planned to open a Theological Seminary in Chisinau, where the subjects would be taught in Romanian and to edit an eparchial newsletter ${ }^{13}$.

After that, Bishop Benedict's activity began to worry both central Soviet authorities as well as the local ones. Moscow's empowered representative, P. Romenski ${ }^{14}$ was unhappy that Bishop Benedict was managing the Eparchy without asking his permission for everything, and in some cases even reproached him over getting involved in the issues beyond his competence. As a result, P. Romenski would send reports to Moscow accusing him of anti-Soviet propaganda and nationalism, demanding his ouster from Moldova ${ }^{15}$. At the insistence of this activist and following the indications of the Soviet authorities, Bishop Benedict (Poliakov) was transferred to another eparchy. If when he came to the

${ }^{10}$ Ibidem,p.279.

${ }^{11}$ ANRM, F.3046, inv.1, d.8, f.85.

12 В.ПАСАТ, op.cit.,p.285.

13 ФлоРинский, Николай, Памяти Архиепископа Венедикта (Полякова), Кишинев, 2001, p.14.

${ }^{14} \mathrm{P}$. Romenski was the empowered representative of the Russian Patriarchate in Chisinau, who submitted regular reports to his superiors about clergy and churches, about the state of religion in MSSR, etc.

${ }^{15}$ Н. ФлоРинский, op.cit., p.14. 
Chair, Eparchy of Chisinau had an enormous debt, when he left, it was in the possession of large sums of money.

By decree of the Patriarch, Bishop's duties were taken over by the newly appointed Bishop of Tiraspol, Nectarie (Grigoriev). At first, he was only an Acting Bishop of Chisinau, but after a year he was appointed Permanent Bishop of the Eparchy of Chisinau and Moldova, pastoring it between 1948 and $1969^{16}$.

In the '50s - '60s, anti-religious policy had gained a growing influence and religious life of MSSR declined. The reason was the indifference of Bishop Nectarie (Grigoriev).

By order of the Committee for the problems of the Russian Orthodox Church, about 71 churches and 12 monasteries were closed during 1948-1953 and the leadership of the Eparchy of Chisinau did not resist in any way.

By an order issued in 1952, Bishop Nectarie prohibited the clergy of the Eparchy of Chisinau and Moldova from performing dedication of wells and shrines, walking with icons during Christmas and Easter, and performing processions with crosses, icons and church flags ${ }^{17}$.

Bishop Nectarie (Grigoriev) collaborated with the State in actions undermining the Church, thus leading the Eparchy of Chisinau to a poor condition.

The next candidate to the episcopal chair of Chisinau was Bishop Bartolomeu (Gondarovski), who led the Eparchy between 1969 and 1972.

Of all the Russian hierarchs who led the Church in Moldova during the atheist regime, only Bishop Bartolomeu stood out because of his work. In a relatively short period, he managed to do many good things: made order in the administrative structures and took care of the household of the eparchial premises. His main merit was that unlike the previous hierarchs, he did not ignore the local Christian specificity, traditions and customs, particularly the use of maternal language in the worship.

His conduct full of rigour, dignity and disobedience led to a worsening of relations with the authorities. Bishop Bartolomeu was not liked by some priests either. He did not take bribes and was very tough with those who had condone this. He disobeyed the corrupt system

${ }^{16}$ В. ПАСАТ, op.cit., p.746-747.

17 V. CIORBĂ,op.cit., p. 180. 
ARS LITURGICA. From the Image of Glory to the Images of the Idols of Modernity composed of the empowered representative in collusion with some priests who wanted to manipulate the hierarch for their own interest. All this led to Bishop's transfer to the Eparchy of Tashkent ${ }^{18}$.

The next bishop appointed was Archbishop IonatanKopolovici. He led between 1972 and 1987. The new appointed bishop was quiet and calculating. He enjoyed the esteem of the clergy and of the faithful. In his work, he did not exceed what was imposed by the State administration and endeavoured to positively resolve all major issues.

He created the Disciplinary Board. He supervised and advised more young people to study theology, who subsequently became clergy of the eparchy. He paid special attention to Japca Monastery - the only one not closed during the atheist regime, which he supported and visited regularly. On October30, 1979, he convened the general assembly of the clergy, attended by all ministers of the Eparchy (the only one during the Soviet times). In 1987 he resigned for health reasons. On May21, 1990, he passed into the land of the righteous.

The last hierarch of the atheist regime was Bishop Serapion (Fadeev), who headed the Eparchy between 1987 and 1989, a period of great transformations in society and in people's consciousness. The political situation added to the deplorable economic context of the USSR economy and national emancipation coincided with the pastoral care of Bishop Serapion. After tens of decades, the Church received its muchwanted freedom. At the insistence of Christians, a number of churches and monasteries reopened and religious life became animated.

There were not enough priests for most of the renovated churches. To solve this drawback, by the initiative of the hierarch, a spiritual school for priests near Capriana Monastery was established. The Metropolitan ordained many young people without sufficient education and training.

Swamped by the wave of major changes, the hierarch had a negative opinion about the national emancipation, did not like services in Romanian, and was authoritarian with the clergy and the faithful.

After the departure of Bishop Serapion, the slander of the Church and church life in MSSR ended, remembered as a black spot in people's memory.

18 А.КиРеЕВ,Епархии и архиереи Русской Православной Церкви в 1943-2002 годах, Москва, 2002, р. 261. 


\section{4. 'Surviving' icons}

One could write a whole chapter of the history of religious life in the Prut-Dniester area on the 'survival' of icons and other religious objects that have gone through the communist ordeal. In vandalized churches and monasteries, church archives were destroyed, murals were drilled with bullets, icons - removed from walls, desecrated or burned at the stake. However, among the faithful ministers of the altar, worthy people were found who had the courage and managed to save a part of the religious cultural heritage. Despite those bitter times, today, true relics glow on the walls of churches, showing faith in the souls of the parishioners.

A special case proves this. In the early ' 70 s, the Soviet authorities decided to close the church in Olanesti village (now Stefan-Voda district) claiming that "it has not been running for a long time". The holy place was destroyed by the Soviet authorities and turned into a warehouse. According to witnesses, the terrifying picture of church destruction was marked by "destroyed icons floating on the Dniester". After burning the church, an icon of St. Mary Magdalene, painted on wood, one of the oldest in the region, dated by some authors from the seventeenth century, was not spared. Authorities "looked for it all over the village". It was rescued by a villager - PintilieVasiliev. The icon was hidden for six years in his attic, and after that, P. Vasiliev gave it to his brother, NichiforVasiliev, who was there on vacation from his native village. NichiforVasiliev, born in a peasant family in Olanesti village, was living in Russia and working within the Department of Bacteriological and Chemical Weapons of the Soviet Army. The Vasiliev family kept the icon of St. Mary Magdalene in Moscow for 30 years. It was restored in the Sofrino workshops, in the Moscow region. In 2010, General Vasiliev returned the icon to the church of Olanesti, built by villagers in the late ' 80 s on the ruins of the one destroyed by the Soviets. The religious relic was welcomed with bread and salt by the church bishop ${ }^{19}$.

19 Ion Xenofontov/ Vladimir Trofimov, „Binefăcători militari ai bisericii Sfânta Parascheva din satul Olănești, raionul Ștefan-Vodă”, in Revista Militară. Studii de securitate şi apărare, no. 1 (9)/2013, p.124-127. 


\section{Icons - part of the national heritage}

Several museums in Moldova keep in their collections, among other vestiges, many icons of high spiritual and heritage value. The National Museum of History of Moldova ${ }^{20}$ (MNIM) has an impressive collection of icons that was established over several years through various ways, its formation beginning with the establishment ${ }^{21}$. The icon collection increased significantly in 1992, after the dissolution of the Museum of the History of Religion (MIR), and the institution assets were transferred to the MNIM heritage.

\section{References}

1. ArhivaNaţională a Republicii Moldova (The National Archive of Republic of Moldova) (ANRM), F. 3046, inv. 1, d. 8, f. 85.

2. CANDU,Teodor/ Moșin, Octavian (eds.), Documente privind istoria Bisericii din RSSM: registrul şi listele clerului (1945-1955) (Documents concerning the History of the Church from Soviet Socialist Republik of Moldavia: Register and clerical lists: 1945-1955), Chişinău,Pontos, 2013.

3. ChIRoșCA, Adelaida, Icoane mariale din patrimoniul Muzeului Național de Istorie a Moldovei (secolele XVII-XX): Catalog, Chișinău, Bons Offices, 2014.

4. CIORBA,Veaceslav, Biserica Ortodoxă din Basarabia şi Transnistria (1940-2010), Chişinău, Pontos, 2011.

5. Munteanu, Ioan, Inviați din Siberii de gheață..., Kiev,"Lumina lui Hristos", 2009.

6. PaSAT, V., Aspru adevăr al istoriei. Deportările de pe teritoriul RSS Moldoveneşti în anii 1940-1950, Chişinău, 2000.

7. Tinonov, Ludmila, Politica Statului Sovietic fată de cultele din R.S.S. Moldovenească (1944-1965),Chişinău, Prut Internaţional, 2004.

8. XENOFONTOV, Ion / TROFIMOV, Vladimir, "Binefăcători militari ai bisericii Sfầnta Parascheva din satul Olănești, raionul Ștefan-Vodă", in

20 The Museum of Military Glory was reorganized into the National Museum of History of Moldova in 1984 (pursuant to Order no. 561 of 21 December 1983, "About museum restructuring").

${ }^{21}$ Adelaida CHIRoșCA, Icoane mariale din patrimoniul Muzeului Național de Istorie a Moldovei (secolele XVII-XX), Catalog, Chișinău, Bons Offices, 2014, p.4. 
Revista Militară. Studii de securitate şi apărare, no. 1(9)/2013.

9. КИРеЕВ, А., Епархии и архиереи Русской Православной Церкви в 1943-2002 годах, Москва, 2002.

10. ПАвлИнчук, Иосиф, Кишиневско-Молдавская Епархия в период с 1944 по 1989 год, Ново-Нямецкиймонастырь, Издательство НовоНямецкогомонастыря, 2004.

11. ПАСАТ, Валериу (отв. ред.), Православие в Молдавии: власть, церковь, веруюшие. 1940-1991. T. 1: 1940-1953, Москва: Российская политическая энциклопедия, 2009.

12. ФлоРИнский, Николай, Памяти Архиепископа Венедикта (Полякова), Кишинев, 2001.

\section{Web sources:}

13. http://moldnova.eu/ro/muzeul-ateismului-de-la-chisinau-locul-deunde-izvora-propaganda-antireligioasa-2468.html/ (AccessedMarch 3, 2017). 